\title{
Marek Hendrykowski Wokół metodologii nauk o sztuce
}

\begin{abstract}
Hendrykowski Marek, Wokół metodologii nauk o sztuce [On methodology in art research]. „Przestrzenie Teorii” 31. Poznań 2019, Adam Mickiewicz University Press, pp. 197-208. ISSN 1644-6763. DOI 10.14746/pt.2019.31.10.

This article deals with the basic issues related to the evolution and methodology of research on art. The author highlights the close relationship between theory and practice of artistic activity and underlines the cognitive advantages stemming from the interdisciplinary approach of formulating and solving research questions in the domain of reflections on art.
\end{abstract}

KEYWORDS: humanities, research on art, methodology, axiology, semiotics

Rozważania o wzajemnej relacji nauki i sztuki zacznijmy od refleksji o charakterze najogólniejszym. Wielorako użytecznym jej wyobrażeniem jest taki model, w którym to, co dotyczy poszczególnych nauk o sztuce, spotyka się z sobą w szerszej przestrzeni humanistyki, zaś to, co humanistyczne, koresponduje i łączy się $\mathrm{w}$ jeszcze rozleglejszym planie z tak zwanymi naukami ścisłymi i eksperymentalnymi: od matematyki i fizyki po wszelkie dziedziny przyrodoznawstwa. Czy rozdzielność i odrębność nauki i sztuki jest rygorystyczna? Kto wie, może warto tę kwestię przemyśleć raz jeszcze. Szczególnie intrygująca jest kwestia wzajemnego przenikania się obu sfer, to znaczy nauki i sztuki.

Warto zauważyć, iż na pewnym poziomie wtajemniczenia uprawianie powiedzmy matematyki czy fizyki bywa sztuka, zaś kunszt artystyczny najwyższego stopnia objawia się i przejawia obocznie do nauki, inspirując i wywołujacc naturalne skojarzenie z nią sama i jej uniwersalnymi prawami. Widać wówczas, po pierwsze, iż odmienność rozmaitych dążeń i dróg eksploracji oraz specyfika poszczególnych dziedzin naukowych wcale nie musi kłócić się z ich funkcjonalną korespondencją i metodologicznym powinowactwem względem kreatywnych dokonań sztuki; po drugie, że pojęcie nadrzędne i swego rodzaju wspólny mianownik operacyjny ich obu stanowi nauka jako wiedza i umiejętność - pojęta najogólniej: z całym bogactwem jej rozmaitych terytoriów badawczych, odmian i metodologii.

Nieprzypadkowo słowem-kluczem od bardzo dawna łączacym obie te komplementarne sfery aktywności ludzkiego umysłu pozostaje ekspery ment. Uczeni i artyści nieustannie czegoś próbuja. W nauce wszystko zaczyna się od „nie wiem”, ,nie rozumiem”, „,nie pojmuje”, „,watpię”. Podobnie dzieje się w sztuce - gdzie punkt wyjścia stanowi „nie umiem”, „nie po- 
trafię”, „nie osiagnę”, „nie da się”, „nie sposób”. Poszukiwanie odmiennych dróg, nieodkrytych dotąd możliwości oraz alternatywnych rozwiązań zbliża naukę i sztukę bez względu na ich takie czy inne podziały.

Nie jest to zreszta nic nowego. Spojrzenia scjentyczne i artystyczne na świat i człowieka bynajmniej nie muszą się nawzajem wykluczać. Jeśli zwrócić się ku niedawnej przeszłości: splot związków łączących sztukę z nauką oraz a contrario naukę ze sztuką okazuje się czymś „naturalnym” i obopólnie inspirującym zarówno w wieku XIX, jak i XX. Spostrzeżenie to dotyczy zwłaszcza intensywnego rozwoju nauk o sztuce: historii sztuki, literaturoznawstwa, szkolnictwa artystycznego, wiedzy o teatrze, muzykologii, zasad architektury, ogrodnictwa etc. Można w odniesieniu do nich mówić o połączeniach i przepływach dwóch rodzajów wiedzy: praktycznej i teoretycznej.

Podobna refleksja dotyczy również horyzontu znacznie odleglejszego. Kategoryczny rozdział nauki i sztuki z kognitywnego punktu widzenia jest wielce wątpliwy. Rozdzielanie tych sfer i przeciwstawianie ich sobie nie służy rozwojowi żadnej z nich. Antyk nie dzielił wiedzy na naukowa i artystyczna. Wprost przeciwnie: nader przemyślnie łączył i traktował na równi jedno i drugie jej oblicze. Zauważmy, iż w ówczesnej konfiguracji dziewięciu muz - córek Zeusa i tytanidy Mnemosyne ('pamięć) - jedne z nich (przykładowo Erato, Euterpe, Kaliope, Melpomenę, Talię, Terpsychorę, Polihymnię) identyfikujemy dzisiaj jednoznacznie ze sztuka, inne (Klio i Uranię) z nauką.

W przeciwstawieniu tym tkwi jednak nie do końca uświadomiony refleks współczesnego separatyzmu, radykalnie, skrupulatnie i wręcz restrykcyjnie oddzielającego domenę sztuki od nauki i odwrotnie, podczas gdy wywodząca się z tradycji antycznego świata kultury siostrzana przyjaźń między różnymi muzami, ich rozmaite zażyłości, terytoria wspólne, strefy pograniczne, filiacje, przymierza, kooperacje i wzajemne oddziaływania współtworzyły sferę niezmiernie doniosłych i owocnych dla kultury kontaktów artystyczno-naukowych.

Nie chodzi tu o bipolarne przeciwstawienie światów antyku i ery nowożytnej. Również w czasach nowożytnych zdarzały się epoki i formacje ideowe nastawione na bliską współpracę uczonych i artystów. Niekiedy więź owa dotyczyła tej samej osoby. Odnajdujemy ją bez trudu w renesansowych dokonaniach i dziełach Brunelleschiego, Bramantego, Dürera, Leonarda, Michała Anioła, Vasariego i innych olbrzymów tamtej ery. Renesansowość zainteresowań jednostki nie stała się jednorazowym, zapomnianym wkrótce epizodem, lecz przetrwała w następnych epokach.

Nie tylko renesans. Kiedy sięgamy do pism Goethego, w jego spuściźnie natychmiast daje o sobie znać artysta w uczonym i uczony w artyście. 
Dwoistość ta kreuje układ wzajemnych sprzężeń - znamienny dla tradycji kultury europejskiej. Figura emblematyczną dla takiego spojrzenia na bliskie niegdyś więzi łączące naukę ze sztuką byłby przede wszystkim Faust, zwłaszcza w wydaniu Goethe’ańskim. W jego skomplikowanej osobowości i przebytej długoletniej drodze duchowej wiek dojrzały i cień starości nieprzypadkowo spotyka się z głęboką tęsknotą i marzeniem o odrodzeniu przez młodość. Niespokojny duch uczonego i równie niezaspokojony w swej ciekawości i nieustannych poszukiwaniach duch artysty jednoczą się w tej osobowości, tworząc mityczno-kulturowy wzorzec twórczego rozwoju jednostki.

Sztuka modernizmu także nie stała w opozycji do nauki. I vice versa, swoiście pojmowana nauka poszukiwała inspiracji w sztuce, czerpiąc z niej, ale też dostarczając swemu alter ego wielu cennych odkryć. Widać to doskonale na przykładzie teatru. Nieprzypadkowo refleksja naukowa (zwłaszcza w dziejach ekspansji Wielkiej Reformy Teatralnej) stanowi integralną część uprawianej wówczas - zarówno w dramatopisarstwie, jak i na scenie, a także w rozlicznych manifestach (Wagner, Antoine, Stanisławski, Craig, Wyspiański, Reinhardt, Meyerhold, Appia i inni) - nowoczesnej sztuki teatru.

$$
* * *
$$

Czy w rozwoju historycznym nauki i sztuki, a także nauk o sztuce, od wieku XVIII po współczesność liczą się wyłącznie kolejne herezje i rewolucje? Owszem, ale nie tylko one. W poszczególnych dziedzinach refleksji nad sztuką daje o sobie znać ciagły konflikt pomiędzy „złym”, bo zachowawczym, tradycjonalizmem a „dobra” innowacja. Trwałość tego, co uchodzi za „naukowe", ma przy takim trybie myślenia charakter paradoksalny. W procesie rozwoju zarówno nauk, jak i sztuk rzekomo „zły” tradycjonalizm nie stanowi bowiem prostego przeciwieństwa a priori „dobrego”, z góry opatrzonego znakiem dodatnim, nowatorstwa.

Innowacyjność w praktyce okazuje się fenomenem o wiele bardziej złożonym i wcale nie tak jednoznacznym, jak zwykli utrzymywać sami nowatorzy. Konieczne do jej rozpoznania i zrozumienia jest trafne odczytanie związku między danym zjawiskiem a sposobem jego zbadania, rozpoznania i zintepretowania. Wiedział już o tym „stary” Tynianow, który po latach okazuje się zadziwiająco „nowym” Tynianowem. W 1927 roku w studium dedykowanym Borisowi Eichenbaumowi pisał on:

Z drugiej strony uproszczony kauzalny sposób patrzenia na szereg literacki powoduje rozziew między punktem, z którego jest on postrzegany (punktem tym zaś sa zawsze szeregi socjalne - zarówno te o znaczeniu podstawowym, jak też dalsze), a samym szeregiem literackim. Konstrukcja zamkniętego szeregu literackiego i obserwacja ewolucji wewnątrz niego skazana jest na fragmentaryczność z racji 
ustawicznych koincydencji z sassiednimi szeregami kultury, życia codziennego, czy w najszerszym znaczeniu, szeregami socjalnymi ${ }^{1}$.

Twórczością tout court, z pełnoprawnym tytułem do nowatorstwa, bywa zarówno teoria, jak i praktyka artystyczna. W obu dziedzinach twórczości stanowiącej bądź domenę naukowa bądź też artystyczną - na krótką metę i w dłuższej perspektywie liczy się tyleż zmienność, co trwałość.

Trwanie i rozwój okazują się w takich przypadkach nie biegunowym przeciwieństwem, lecz dwoma komplementarnymi aspektami zarówno samej instytucji nauki, jak i jej twórczego uprawiania. Pożądana, więcej konieczna i niezbędna - ciagłość ich rozwoju przenika się ze „skokami”, „zwrotami” i „przełomami”, niczym nieprzewidywalny bieg górskiego strumienia. Jedno nie wyklucza drugiego. Wręcz przeciwnie - stanowi czynnik inspirujący i nieustannie stymulujący dynamikę twórczego rozwoju i dalsze poszukiwania: zarówno poszczególnych dziedzin i dyscyplin, jak i refleksji artystycznej oraz naukowej w ogóle.

W naukach o sztuce - od Winckelmanna, Lessinga, Schellinga, Hegla, Warburga, Wölfflina i Panofsky'ego po Jakobsona, Tynianowa, Mukařovský'ego, Ingardena, Bachtina, Łotmana i Uspienskiego - kolejne przełomy wydają się, każdy na swój sposób, ważniejsze od akademickiego ładu i umiarkowania. Wydają się ważniejsze, chociaż niekoniecznie zawsze nimi sa. Jedno i drugie łączy bowiem doniosły związek funkcjonalny p o w tó r z e nia i in now a cji. W wyrażeniu „ciagła zmiana”, paradoksalnie, dochodzi do głosu nie tylko czynnik zmienności, ale i czynnik trwania i ciagłości.

Społeczna regulacja zasad funkcjonowania nauki, w tym zwłaszcza nauk o sztuce, obejmuje nie tylko nurt główny, najczęściej utożsamiany z akademickościa, lecz także nurty peryferyjne: rwące umocnione brzegi powszechnie przyjętych i obowiąujących ustaleń porywy nowatorskich idei. Ciągły konflikt między dynamicznymi i niespokojnymi peryferiami a statycznym centrum stanowi źródło niezbędnych przemian i wymian, za sprawą których obrazoburcze koncepcje pojawiające się na peryferiach nauki i sztuki z biegiem czasu zajmuja eksponowane miejsce w centrum ich obu i tak dalej, da capo al fine.

Praktyka twórcza poszczególnych dziedzin sama w sobie jest czynnikiem zmiany pierwszorzędnie ważnym, ale nie jedynym. Nie należy jej przeciwstawiać nowatorskim koncepcjom teoretycznym, nieraz wyprzedzającym praktykę artystyczną. Zmienność sztuk przebiega dwutorowo. Z wielopokoleniowego doświadczenia wiadomo, iż wszelka nauka rozwija się dzięki nowym koncepcjom zwanym teoriami.

${ }^{1}$ J. Tynianow, O ewolucji literackiej, przeł. A. Pomorski, [w:] tegoż, Fakt literacki, Warszawa 1978, s. 45. 
XVIII-wieczny rozwój refleksji teoretycznej nad sztuką wywarł przemożny wpływ zwłaszcza na sposób wartościowania twórczości artystycznej. Dopiero w wieku XIX i XX można mówić o znamiennym rozszczepieniu ustanowionej wcześniej i wielorako usankcjonowanej aksjologii - w związku z pojawieniem się i ekspansją nurtów „nieakademickich”: rozmaitych konwersji, wystapień, diaspor, kolejnych „izmów” i awangard, które pozostawały w ostentacyjnej nieraz opozycji do uznanych „,akademickich” systemów estetycznych i koncepcji sztuki (tańca, muzyki, opery, literatury, teatru, grafiki, malarstwa, rzeźby, filmu etc.).

$$
* * *
$$

Łącząca praktykę i teorię sztuki więź funkcjonalna ma charakter intrygujący i nieporównanie bardziej złożony, niż się na ogół sądzi. Nie organizuje jej jeden typ determinizmu. Wielce wattpliwe, czy w ogóle można jej przypisać jakikolwiek prosty mechanizm determinizmu. We współczesnych naukach o sztuce: w literaturoznawstwie, historii sztuki, muzykologii, teatrologii, filmoznawstwie i innych dziedzinach nowe teorie wyprzedzaja praktykę twórczą równie często, jak nowa praktyka artystyczna zapowiada i poprzedza historycznie pojawianie się alternatywnych teorii sztuki.

Wyjąwszy matematykę, nie ma w nauce „czystych” teorii. Jedne z nich mogą wydawać się czymś czysto abstrakcyjnym i całkowicie oderwanym od praktyki danej dziedziny, kiedy indziej okazują się mieć z nią ścisły, co nie znaczy, że momentalnie oczywisty, związek. Teoria bywa „czysta” tylko do pewnego momentu. Jeśli jest prawdziwa, wcześniej czy później odsłoni i ukaże użyteczność swych zastosowań w odniesieniu do sfery praktycznej. W naukach ścisłych taką teoretyczno-praktyczną więź i moc wyjaśniająca ma właśnie przywołana przed momentem matematyka w odniesieniu do fizyki i vice versa.

Nowe teorie w nauce czerpią swoją oryginalność ze źródła zaprzeczenia. Negatywizm i związane z nim sceptyczne podejście prowadzą do nowego postawienia problemu. Nadają wagę i znaczenie oryginalnym teoriom, pozostając niezbywalną funkcją ich pojawiania się, oddziaływania i funkcjonowania w życiu społecznym. Nowa interpretacja nieuchronnie pociaga za sobą zakwestionowanie i dekonstrukcję poprzednich interpretacji, utrzymujących się do pewnego momentu i uważanych dotąd za prawomocne.

Reinterpretacja dotychczasowych poglądów - ujmowana jako fenomen naukowy, katalizator zachodzących zmian i przejaw rozwoju - z natury swej poszukuje czegoś odmiennego, wywraca na nice to, co dotąd oczywiste, kwestionuje i zaprzecza. Im bardziej jest nowatorska, tym bardziej nieuchronnie dekonstruuje wcześniejsze ustalenia, przekonania i koncepcje. Niestrudzony i niedostrzegalny kornik nauki nigdy nie przestaje drążyć. 
Zarazem nauka nie rozwija się w sposób linearny. Podobnie jak sztuka, istnieje i żyje pełnią w długim trwaniu. Dawne pytania i naukowe intuicje mają to do siebie, że powracaja co pewien czas jako kwestie stawiane na nowo wokół dawnych dylematów. Źródłem zmiany w poszczególnych dziedzinach naukowych jest inny od dotychczas kursujacych sposób postawienia pytania, nowy klucz odczytania bądź inny repertuar przykładów. Echo historyczne tych ponowionych pytań bywa nieraz bardzo odległe. Nowe odpowiedzi, tak inspirujące i cenne z punktu widzenia nauki, okazują się rewelacyjne i poznawczo doniosłe właśnie dzięki temu, że ktoś owe dawne pytania i teorematy potrafił odkrywczo przeformułować, nadając im nowy sens i wyposażając w odmienną argumentację.

$$
* * *
$$

Najbardziej pociagająca i fascynująca w nauce jest czasoprzestrzeń rozciagająca się pomiędzy ukonkretnioną teorią a uogólnioną praktyką naukowej refleksji. Można ją opisać jako pole napięć między tym, co pomyślane (teoria), a tym, co wykonalne (praktyka). Na to, by oba bieguny mogły się z sobą zjednoczyć, potrzeba nieraz wiele czasu. Niekiedy praktyka twórczego eksperymentu wyprzedza daleko teorię, kiedy indziej teoria (na przykład zapisana mniej lub bardziej intuicyjnie w manifestach artystycznych) sygnalizuje i zapowiada kierunek przemian w sferze twórczości.

Czasoprzestrzeń ta wyznacza zarówno sferę diachronii, jak i pozostaje - co szczególnie intrygujące - sferą wielkiej synchronii, w ramach której dokonuje się rozwój, przepływ i ewolucja określonych idei: od fazy ich pojawienia się i narastającej ekspansji, poprzez kulminacyjną fazę ich dojrzałego rozwoju, aż po wyczerpanie. Niektóre z tych faz (na przykład przełom lingwistyczny w XX-wiecznym rozwoju literaturoznawstwa i nauk o sztuce) wykazują przy tym nadzwyczajną dynamikę i żywotność.

Pojęciowa nośność i żywotność wielkich koncepcji humanistyki, do których należą przykładowo: mimesis i kátharsis Arystotelesa, ut pictura poesis w wersji Horacego i w wersji Gottholda Ephraima Lessinga, cząstka dyskretna języka w koncepcji Jana Baudouina de Courtenay i Mikołaja Kruszewskiego, ego, superego i id w ujęciu Sigmunda Freuda, budowa funkcjonalna znaku w modelowym ujęciu Ferdinanda de Saussure'a, naprzemienny rozwój stylów i epok Heinricha Wölfflina, współczynnik humanistyczny Floriana Znanieckiego, miejsca niedookreślenia Romana Ingardena - na tym wydaje się polegać.

Podobnie jak: polifoniczność i dialogowość Michaiła Bachtina, kultura zabawy i homo ludens Johana Huizingi, definicja funkcji poetyckiej jako językowej nadorganizacji utworu autorstwa Romana Jakobsona, archety- 
py Carla Gustawa Junga, ikonografia i ikonologia Erwina Panofsky'ego, ucieczka od wolności Ericha Fromma, teoria źródeł totalitaryzmu Hannah Arendt, opozycja sacrum-profanum Mircei Eliadego, „medium is the message" Marshalla McLuhana, struktura mitu według Claude’a Lévi-Straussa, rama modalna Borisa Uspienskiego, historiozofia długiego trwania Fernanda Braudela, ikonosfera Mieczysława Porębskiego, kontrafaktura tekstu Jerzego Ziomka i szereg innych.

Oczywiście, również „nieśmiertelność” owych wielkich konceptów teoretycznych ma charakter względny i ograniczony. Należy ją oceniać nie w kategoriach absolutu, lecz mając zawsze na uwadze określony horyzont i kontekst historyczny. Znamienną cechą takich koncepcji jest powrotność i w praktyce niewyczerpana użyteczność przy rozwiązywaniu nie tylko rozmaitych nowych zadań i kwestii badawczych, ale również, co należy szczególnie mocno podkreślić (Picasso, Strawiński, Joyce, Chlebnikow, Meyerhold, Griffith, Chaplin, Murnau, Wiertow, Kuleszow, Eisenstein, Witkacy, Welles i inni), rozmaitych wyzwań artystycznych.

Ruch myślowy i przepływ inspiracji odbywają się tu nie w jedna, lecz w obie strony. Hegel i Schelling tworzyli swa filozofię (nie tylko sztuki!), czerpiąc inspirację z wnikliwej obserwacji dzieł i porywów ducha występujących w tragedii, powieści, poezji etc. Nietzsche i Freud zawdzięczali niezmiernie wiele pierwszy Wagnerowi, drugi Szekspirowi. Głębinowy wpływ teorii archetypów Carla Gustawa Junga na twórczość Felliniego (zwłaszcza na Stodkie życie, Osiem i pót, Giuliettę i duchy i Amarcord) budzi do dzisiaj żywe zainteresowanie interpretatorów.

Wszechstronność możliwych zastosowań - użytecznych dla opisu, analizy i interpretacji zarówno poszczególnych dzieł, jak i ich serii - przekonuje, że pomiędzy naukami i metodologiami rozciaga się otwarta przestrzeń wymiany i wzajemnej inspiracji. W dziejach humanistyki XX wieku istniały formacje i zespoły naukowe (między innymi lwowska szkoła matematyczna, OPOJAZ, praska szkoła strukturalna, grupa Tel-Quel, tartuska szkoła semiotyczna, stowarzyszenie badaczy wczesnej historii kina DOMITOR i in.), które oddziaływały w sposób niezmiernie inspirujący na ruch intelektualny w różnych naukach: od lingwistyki i semiotyki, poprzez historię sztuki, literaturoznawstwo, muzykologię, aż po teatrologię i filmoznawstwo.

Niełatwy i najczęściej ryzykowny wysiłek zmierzający do konstruowania przęseł i śmiałego przerzucania metodologicznych mostów pomiędzy poszczególnymi dziedzinami humanistyki daje o sobie znać na wielu możliwych przykładach. Elita światowa naukowców i badaczy sztuki działała i nadal działa w tym kierunku, mając ostrą świadomość zagrożeń poznawczych wynikających z nadmiernej specjalizacji dyscyplin skoncentrowanych wyłącznie na sobie. Wielorako uzasadniona i pragmatycznie wskazana, 
interdyscyplinarność szerszej refleksji naukowej ciąle jednak natrafia na opór w programowaniu rozwoju i podejmowaniu strategicznych decyzji, w praktyce dając o sobie znać rzadziej niż byłoby to wskazane i realnie potrzebne.

Interdyscyplinarność jako wytyczna prowadzenia badań naukowych nad sztuką bądź sztukami nie jest ani niezawodną recepta, ani żadnym panaceum. Nie chodzi przy tym wcale o nia sama, lecz o perspektywy badawcze, jakie ona otwiera, i skutki poznawcze, które wywołuje. Przełamywaniu sztucznych grodzeń, barier i ostro strzeżonych posterunków granicznych dzielących poszczególne nauki (nie tylko nauki o sztuce) dobrze służą interdyscyplinarne kooperacje. Ich modelowym przykładem sprzed pół wieku może być pamiętna współpraca między lingwistą Romanem Jakobsonem a etnologiem Claude'em Lévi-Straussem nad wspólnie przeprowadzoną przez nich lingwistyczna, literaturoznawczą i antropokulturową analizą Kotów Charles'a Baudelaire'a ${ }^{2}$.

$$
* * *
$$

Poszczególne wyemancypowane nauki generalnie żywią dzisiaj nikłą świadomość własnej immanentnej interdyscyplinarności. Takiej na przykład jak: nauka o literaturze wobec językoznawstwa ${ }^{3}$ czy z natury swej interdyscyplinarne: historia sztuki, kulturoznawstwo, muzykologia, teatrologia, filmoznawstwo i medioznawstwo. Jeśli twierdzę, iż w poszczególnych naukach o sztuce występuje obecnie znaczny deficyt (a niekiedy całkowity zanik) świadomości ich owocnego zadłużenia względem innych, niekiedy bardzo odległych, dyscyplin, nie mam na myśli prostego potwierdzenia faktu zaciągniętego niegdyś długu, lecz coś o wiele ważniejszego, a mianowicie pogłębioną refleksję metodologiczną nad rozlicznymi pożytkami płynącymi z programowego eklektyzmu komplementarnie stosowanych metod.

$\mathrm{W}$ praktyce badawczej występującej w rozmaitych dziedzinach nauki wielokrotnie bywa tak, że czystość metodologiczna prowadzi do zawężania poznawczego horyzontu. Aby temu skutecznie zapobiec, warto być programowo eklektycznym: historykiem sztuki, muzykologiem, literaturoznawca, teatrologiem, filmoznawca, medioznawca, antropologiem kultury, kognitywista, semiotykiem wreszcie. Warto choćby dlatego, że metodologiczne ryzyko czerpania z rozmaitych - ościennych i odmiennych - dziedzin równoważą per saldo korzyści czerpane $\mathrm{z}$ takiej strategii.

${ }^{2}$ R. Jakobson, C. Lévi-Strauss, „Koty” Baudelaire’a, przeł. M. Żmigrodzka, [w:] Sztuka interpretacji, wybór i oprac. H. Markiewicz, t. 1. Wrocław-Warszawa-Kraków-Gdańsk 1971.

${ }^{3}$ Nawiązuję w tym miejscu do słynnego artykułu Romana Jakobsona: Poetyka w świetle językoznawstwa, przeł. K. Pomorska, „Pamiętnik Literacki” 1960, vol. 51, z. 2. 
Rzeczą godną uwagi jest przy tym umiejętne łączenie rozmaitych - nieraz zaskakująco dalekich - kompetencji badawczych. W niektórych przypadkach bywa ono wręcz konieczne, jak choćby w odniesieniu do studiów podejmowanych nad komunikowaniem, językiem, metafora, symbolem, budową i funkcjami znaku, trwaniem i ewolucją kultury, zrównoważonym rozwojem, miastem i wsia, pamięcia, tradycja, rozmaitymi rodzajami i gatunkami, stylem i kompozycja, narracja, czasem i przestrzenia, autotelicznościa, estetyka, artyzmem, sztuką i jej kierunkami, kulturą audiowizualna.

Interdyscyplinarne przekroje dobrze służą nie tylko danej wiązce nauk. Wystarczy przypomnieć, ile nowocześnie uprawiana refleksja historyczna, kojarzona z pracami Roberta Sklara ${ }^{4}$, Jerzego Topolskiego ${ }^{5}$, Haydena White'a ${ }^{6}$, Franklina R. Ankersmita ${ }^{7}$ i Roberta Rosenstone'a ${ }^{8}$ czy Ewy Domańskiej $^{9}$ zawdzięcza umiejętnie zaadaptowanym i rozwiniętym konceptom z zakresu komparatystycznie traktowanej narratologii, sama zreszta szczodrze odwzajemniajac ze swej strony cenne inspiracje swoim wierzycielom.

Podejmowanie takich złożonych zadań i twórcze rozwiąywanie problemów badawczych, adaptujące zdobycze metodologiczne innych dyscyplin, ma w humanistyce jeszcze jeden istotny walor. Uzmysławia ono, iż zarówno kultura i sztuka, jak i nauka - widziane z odpowiednio rozległej perspektywy - nie są odrębnymi terytoriami sztucznie oddzielonymi od innych, lecz tworzą systemową jedność wyższego rzędu. Łatwo się o tym przekonać, sięgając po konkretny przykład. O tyle bardziej intrygujący, iż zakorzeniony w kulturze i sztuce popularnej.

Styl gonzo, zainicjowany w amerykańskim dziennikarstwie reportażowym początku lat sześćdziesiątych i siedemdziesiątych XX wieku (Bill Cardoso, Terry Southern, H.S. Thompson, Gene Youngblood i inni), po kilku dekadach wszechstronnego rozwoju obejmuje dzisiaj swym zasięgiem wachlarz różnych egzogennych zjawisk kulturowych i artystycznych. Funkcjonuje więc z powodzeniem w fotografii, spotykamy go w happeningu i performansie, w prezentacjach spod znaku body artu, w grafice, malarstwie, rzeźbie, komiksie i wideo arcie, a także w dokumencie filmowym,

${ }^{4}$ R. Sklar, Movie-Made America. A Cultural History of American Movies, London 1978.

${ }^{5}$ J. Topolski, Metodologia historii, Warszawa 1968; tenże, Jak się pisze i rozumie historię: tajemnice narracji historycznej, Warszawa 1996.

${ }^{6}$ H. White, Poetyka pisarstwa historycznego, red. E. Domańska, M. Wilczyński, Kraków 2000; tenże, Proza historyczna, red. E. Domańska, Kraków 2009.

${ }^{7}$ F. Ankersmit, Narracja, reprezentacja, doświadczenie, red. i wstęp E. Domańska, Kraków 2004.

${ }^{8}$ R.A. Rosenstone, Visions of the Past. The Challenge of Film to Our Idea of History, Cambridge, MA, London 1995; tenże, History on Film. Film on History, London, New York 2006.

${ }^{9}$ E. Domańska, Mikrohistorie. Spotkania w międzyświatach, Poznań 1999; taż, Historie niekonwencjonalne. Refleksja o przeszłości w nowej humanistyce, Poznań 2006. 
animacji i filmie fabularnym. Jego modelową reprezentacją w dziedzinie beletrystyki jest ponadto słynna powieść Huntera S. Thompsona Fear and Loathing in Las Vegas: A Savage Journey to the Heart of the American Dream (1971) z rysunkowymi ilustracjami Ralpha Steadmana ${ }^{10}$.

Wybrałem spośród wielu możliwych już znanych właśnie ten niezbyt znany i niekoniecznie oczywisty przykład z trzech co najmniej powodów. Po pierwsze dlatego, że dotyczy on dnia dzisiejszego i serii zjawisk kulturowych złożonej z wielu różnych przejawów dostrzegalnych w procesach współczesnej synchronii rozwojowej. Po drugie, fenomen gonzo trwa nadal i funkcjonuje w dostatecznie długim trwaniu historycznym. I po trzecie, łaczy on w sobie sferę sztuki (aspekt artystyczny) ze sfera nie-sztuki (aspektem pozaartystycznym), co stwarza szczególnie ciekawą perspektywę dla tyczącej go refleksji antropokulturowej i komunikologicznej. Gonzo jest bowiem tyleż efektem kontrkulturowej rafinady estetycznej w logosferze, ikonosferze i audiosferze, co znamiennym przejawem wielokierunkowych dążeń narracyjnych współczesnej kultury mediów. Zasługuje więc ze wszech miar na to, by badać go interdyscyplinarnie: przy zastosowaniu rozmaitych alternatywnych metod i narzędzi.

$$
* * *
$$

Pozostaje nam jeszcze do podjęcia - przez cały czas obecna w tle niniejszego eseju - pierwszorzędnie istotna kwestia związku pomiędzy teorią i praktyką w naukach o sztuce. Aby móc ją rozstrzygnąć, sięgnijmy prosto do źródła. Prefiguracją rozwoju humanistycznej refleksji o charakterze metodologicznym pozostaje niezrównane i inspirujące aż po dzień dzisiejszy dzieło Arystotelesa, zwłaszcza jego Metafizyka i Poetyka. To on bowiem na kartach Metafizyki sformułował genialną w swej prostocie myśl: „celem wiedzy teoretycznej jest prawda, a wiedzy praktycznej działanie".

W szerszym planie jednak, gdy mowa o nauce o nauce, czyli filozofii nauki, w jej najgłębiej sięgających poszukiwaniach i aspiracjach metodologicznych, praojcem wszystkich metodologów okazuje się żyjący od Stagiryty o całe stulecie wcześniej Sokrates. Najznakomitszy ze starożytnych filozofów, jak nikt inny zasługuje na miano tego, od kogo na długo przed Arystotelesem rozpoczyna się tworząca spójny system myślowy refleksja humanistyczna tego rodzaju - refleksja nad sztuką i nauką równocześnie.

„Scio me nihil scire” w wersji łacińskiej i „Oida ouden eidos” w domniemanej wersji greckiej zawiera w sobie najdalej idący sceptycyzm epistemologiczny jako dewizę i kierunek dochodzenia do prawdy poprzez oczyszczenie

${ }^{10}$ W roku 1998 powieść Thompsona doczekała się głośnej ekranizacji pod tytułem Las Vegas Parano w reżyserii Terry'ego Gilliama, z Johnnym Deppem i Benicio Del Toro. 
pola refleksji z wszelkich istniejących wcześniej domniemań. Nie chodzi tylko o samo przyznanie się mędrca do niewiedzy. W gruncie rzeczy nieśmiertelną myśla, którą zaproponował swym następcom do przemyślenia wielki filozof, mówiąc „wiem, że nic nie wiem”, jest coś więcej, mianowicie: programowo uprawiany sceptycyzm i metodologiczny reset-jako punkt wyjścia wszelkich poczynań badawczych: w sztuce, w nauce i poza nimi.

W koncepcji Sokratesa i w głębokich związkach łączaccych ją z późniejszymi ideami Arystotelesa metodologia jako postawa badawcza z założenia swego stanowi nie doktrynę, lecz wprost przeciwnie - postulowaną i uprawiana krytykę metodologiczna. Metodologia znaczy tu tyle, co ustawiczna, nigdy niekończąca się krytyka metod (wszelkich dotychczas stosowanych metod) będąca świadomie przyjętym punktem wyjścia i początkiem drogi ku poznaniu.

$$
* * *
$$

Znamienne, iż wymienione na początku wielkie idee i koncepcje metodologiczne humanistyki, choć wyrastały z podstaw określonej dziedziny naukowej, wykraczały daleko poza horyzont jednej z nich. Możemy toczyć i zapewne długo jeszcze będziemy wzniecać - niekończące się spory o autorstwo dzieła sztuki, narrację, powinowactwa przez fabułę, o formacje, kierunki i style artystyczne, o zakres i powszechność występowania archetypów i mitów, o kulturowe znaczenie konfliktu między „centrum” a „peryferiami” nauk o sztuce, o to, czy środek przekazu istotnie sam jest przekazem, albo o to, czy metaforę można zobaczyć.

Realnie jednak w każdym z tych przypadków i w odniesieniu do każdego z podejmowanych zagadnień liczy się co innego, a mianowicie: mobilizująca zdolność wydobycia potencjału naukowego nie jednej, lecz wiązki wielu niezbędnych dziedzin i ich wspierających się nawzajem metodologii. Niezależnie od takich czy innych ustaleń i doraźnych rozstrzygnięć, jakie (nie)ostatecznie zapadną w owych sporach, ich cel nadrzędny każdorazowo odsłania przed nami nieocenioną wartość poznawcza - w postaci nowych ujęć, propozycji i dokonań badawczych, których źródło inspiracji stanowi interdyscyplinarna synergia metodologiczna.

PS. Jeśli w trakcie lektury niniejszych rozważań nasunęło się Adresatowi przypuszczenie, iż autor z jakiegoś względu zachowuje sceptyczny dystans wobec „potrząsania nowości kwiatem” w nauce, sztuce i naukach o sztuce, a jednocześnie skłonny jest bronić doniosłej roli nowatorstwa zapisanego w przeszłości i tradycji, niech wie, że natrafił na ważny refleks autorskiej intencji. 


\section{BIBLIOGRAFIA}

Bal M., Wędrujace pojęcia w naukach humanistycznych. Krótki przewodnik, przeł. M. Bucholc, Warszawa 2012.

Bauman Z., Kultura jako praxis, przeł. J. Konieczny, Warszawa 2012.

Berleant A., The Aesthetic Field: A Phenomenology of Aesthetic Experience, Springfield 1970.

Burszta W.J., Monokultura i mediatyzacja. W strone kulturoznawstwa krytycznego, „Przegląd Kulturoznawczy” 2014, nr 2 (20).

Compagnon A., Demon teorii. Literatura a zdrowy rozsqdek, przeł. T. Stróżyński, Gdańsk 2010.

Eagleton T., Koniec teorii, przeł. B. Kuźniarz, Warszawa 2012.

Feyerabend P.K., Przeciw metodzie, przeł. S. Wiertlewski, Warszawa 1996.

Hopfinger M., Kultura audiowizualna u progu XXI wieku, Warszawa 1997.

Kuhn Th., Struktura rewolucji naukowych, przeł. H. Ostromęcka, Warszawa 2001.

Miejsca wspólne: szkice o komunikacji literackiej i artystycznej, red. E. Balcerzan, S. Wysłouch, Warszawa 1985.

The Renewal of Cultural Studies, ed. P. Smith, Philadelphia 2011.

Youngblood G., Expanded Cinema, New York 1970.

Ziomek J., Powinowactwa literatury. Studia i szkice, Warszawa 1982. 